UDC [325.14+616.97] $(470+571)$

DOI: $10.21668 /$ health.risk/2019.3.08.eng

\title{
ASSESSING POTENTIAL THREAT OF HIV-INFECTION SPREAD IN RUSSIA BY MIGRANTS FROM ASIAN AND AFRICAN COUNTRIES
}

\author{
R.V. Dmitriev ${ }^{1,2}$ \\ ${ }^{1}$ Institute for African Studies of the Russian Academy of Sciences, 30/1 Spiridonovka Str., Moscow, 123001, \\ Russian Federation \\ ${ }^{2}$ Institute of Geography of the Russian Academy of Sciences, 29 Staromonetnyi lane, Moscow, 119017, Russian Federation
}

Recently there has been a growth in number of HIV-infected people among migrants in Russia. Migrants from Asian and African countries are especially dangerous in this respect. An initial stage of HIV epidemic is observed in 13 countries out of total 97 in these two macro-regions (without the Democratic People's Republic of Korea). A generalized stage in the process when HIV spreads beyond common risk groups is detected on the Seychelles and in continental African countries south from Sahara, excluding countries located in the Horn of Africa and several Western African countries. All the other countries in the examined macro-regions are somewhere in-between as regards HIV territorial diffusion as a concentrated stage in the epidemic process is observed there and the disease is predominantly spreading within several risk groups; however, it is highly likely to spread beyond them in the nearest future.

Hierarchical cluster analysis was accomplished as per four aggregated groups of parameters (the current situation in these countries as regards HIV spreading; inflow of migrants from them into Russia; migrant inflow differentiation as per its chronological and chorologic parameters). It allowed assigning all Asian and African countries into four groups as per a size of threat they imposed for Russia concerning HIV-infection spread. The first group included countries with the highest threat (Uzbekistan, Kazakhstan, and Tajikistan). The second group meant a high threat (most North African countries and Middle-East countries, South and Eastern Asian countries, and Nigeria as well). The third group meant an average threat (most African countries located to the south from Sahara and South-Eastern Asian countries as well as some countries excluded from the second group such as Libya, Saudi Arabia, Qatar, Kuwait, Nepal, Bangladesh, Sri Lanka, Laos, Cambodia, and the Philippines). The fourth group included countries that imposed a low threat (all the rest, but there were only few of them, Gambia, Liberia, Niger, Burkina Faso, Gabon, Democratic Republic of Congo, Malawi, Botswana, Eswatini, Lesotho, Eritrea, Djibouti, Oman, Brunei, Butane, and Myanmar). Nevertheless, overall contribution made into HIV spread in Russia by migration is still insignificant. Return migration of people from Russia into a country of their origin is a much greater threat within cross-border HIV diffusion.

Key words: HIV-infection, spread, territorial diffusion, risk groups, cluster analysis, international migration.

HIV-infection was first detected in Russia in 1987 among Russian citizens who had had some sexual contacts with infected foreigners, "mostly, from African countries" [1]. HIV in Russia, just as all over the world, was probably first detected among homosexual men [2]. Obviously it was the case with other former Soviet Republics. Thus, for example, first HIV cases in Tajikistan were registered in 1991 among helicopter pilots who had previously worked in Africa and "got infected due to homosexual contacts with locals" [3].
However, by now the virus has spread beyond HIV risk groups that are usually determined by epidemiologists in many countries all over the world, Russia included. Although migrants are not conventionally assigned into such groups, it was migration that gave way for spatial diffusion of HIV infection between regions and countries in the past (and it still remains a pathway for this infection on multiple territories) $[4,5]$.

Recently in the RF there has been permanent, although uneven, growth in a share of

(C) Dmitriev R.V., 2019

Ruslan V. Dmitriev - Candidate of Geographical Sciences, Senior Researcher (e-mail: dmitrievrv@yandex.ru; tel.: +7 (495) 691-00-61; ORCID: https://orcid.org/0000-0003-4018-9832). 
foreign citizens among people who are "patients with primarily detected antibodies to HIV"; this share went up from $2.9 \%$ in 2011 to $4.3 \%$ in $2015^{1}$. The consequent period was an exception as the parameter dropped to $1.2 \%$ in $2016^{2}$ and to $0.8 \%$ in $2017^{3}$ due to an introduction of a new statistical report form which differed from previously used ones. In Moscow, for example, it resulted in a decrease in "morbidity with HIV-infection" from 60.5 cases in 2015 to 19.5 cases per 100 thousand people in 2016; but an ascending trend still occurred in 2017 as this parameter grew by $23.3 \%$.

Our research goal was to determine potential threats of HIV-infection being spread in Russia by migrants from African and Asian countries.

Data and methods. Some experts state that "there are no grounds to believe that nowadays foreigners exert considerable impacts on HIV spread in Russia" [6]. But at the same time, a growth in relative and absolute number of migrants with detected HIVinfection in Russia (primarily due to greater number of them being examined by medical personnel) has naturally attracted a lot of experts' attention to the issue and resulted in greater number of scientific works on the subject.

Most such works dwell on analyzing regional distribution of migrants with HIV over administrative territories in the RF. Thus, data collected in the Far East [7] and North Caucasian [8] Federal Districts and distributed as per countries of migrants' origin allowed exploring detection of HIV-infection among examined foreign migrants. Research performed on migrants in Saint Petersburg led to a very remarkable conclusion on HIV subtype A1 prevailing in the city; that is, on migration processes being "secluded" between this RF region and Central
Asia [9]. But still, it was shown that in Russia as a whole over the last years there has been a growth in a share of migrants from Ukraine among those with primarily detected HIV infection and a decline in a share of those who came from other CIS states [10]. Experts took data collected in Omsk region and showed [11] that, on one hand, HIV-infection spread was rather low among labor migrants but, on the other hand, "they had a very irresponsible attitude towards medical examinations and tended to practice unsafe sex" and it could result in "deteriorated epidemiologic situation, both in a region where they temporarily resided and in a country of their origin" [12]. Also migrants from former Central Asian USSR republics were usually not so well aware about HIV/AIDS prevention [13] than their counterparts from the Eastern Europe [14].

It is interesting to note that most papers focusing on a role played by migration in HIV infection spread (including abovementioned ones) usually dwell on analyzing the current situation and developing applied aspects of the matter. They are frequently based on quantitative data that are not so easily available for collection, but nevertheless, their predictive potential is rather low. Given that, mathematical and statistical modeling seems to be quite useful for obtaining new knowledge on potential trends in migration of HIV-infected people, current demographic situation as per HIV and ways to regulate it. The present research, in no way being comprehensive and complete, is just a tentative step into this direction.

Our process of data collection and generalization, as regards its contents, consisted of three stages. The first one focused on migration from Asian and African countries to Russia. To assess its scales, we took data provided

\footnotetext{
${ }^{1}$ The situation with HIV-infection in Russia (in 2015). Available at: http://mednet.ru/ru/czentr-monitoringa-tuberkuleza/produkcziya-czentra/analiticheskie-obzory.html (date of visit January 12, 2018).

${ }^{2} \mathrm{HIV}$-infection in Russia in 2016. Available at: http://mednet.ru/images/stories/files/CMT/2016vich.pdf (date of visit December 22, 2017).

${ }^{3}$ The situation with HIV-infection in Russia in 2017. Available at: http://mednet.ru/images/stories/files/miac/2017_vich.pdf (date of visit August 25, 2018).
} 
by the Russian Federal State Statistic Service (Rosstat) $^{4}$ on migration flows from all countries in the world into each RF region over a period from 1993 to 2015 inclusive. Still, there was no consistency in determining this notion, "a migrant", by statistical authorities (and not only them) in the RF over the whole examined period. Given that, we examined four time periods in our analysis as data on migration into $\mathrm{RF}$ available for each of them were comparable. These periods were 1997-2000, 2003-2006, 2007-2010, and 2011-2015. Although certain changes in migration accounting appeared at boundary periods of 2006-2007 and 2010-2011, they had some effects on calculating a number of migrants and not on determining countries of their origin.

So, we obtained ultimate data on intensity of migration flows from Asian and African countries into each RF region and analyzed them. Data on countries from which migrants moved to each RF region in each year of the examined time period gave grounds for preliminary distribution of all the countries into four groups as per scales of their "migration" activity. These four groups were "local" countries (migrants from them moved to less than $1 / 4$ of all the RF regions); "regional" ones (from $1 / 4$ to $1 / 2$ ), "macro-regional" ones (from $1 / 2$ to $3 / 4$ ), and "federal" ones (more than $3 / 4$ ).

The only exception here is Crimea and Sevastopol and they are not considered in our research as they became $\mathrm{RF}$ regions only at the end of the examined time period and statistical data on these two RF regions are scarce; they can't give grounds for any valid conclusions on migration-related "threats". As for foreign countries, we didn't consider some of them (such as South Ossetia or Abkhazia) as they have only recently become independent states.

In this relation the second stage involved work with sources, collection, and systemati- zation of data on HIV spread in Asian and African countries and their analysis for a period from 1993 to 2015. Our primary data sources were two databases that integrated national data on all the world countries, namely UNAIDS, the United Nations AIDS program [15] and the WHO database [16].

To assess rate of HIV spread, we took dynamics of expected number of people in each risk group as our basic parameter (risk groups included sex workers; men who had homosexual contacts; drug addicted people who took injection drugs; transgenders; people in prisons) and HIV prevalence in each of them. UNAIDS and the WHO give recommendations on how to distinguish between different stages in HIV epidemics: the initial stage means HIV has been present in a country for a long time but its prevalence in each risk group stably doesn't exceed 5\%; the concentrated stage means that HIV primarily spreads among people from risk groups and incidence in at least one of them exceeds $5 \%$ while incidence among population in general ${ }^{5}$ doesn't exceed $1 \%$; the generalized stage means HIV spread beyond risk groups and incidence among a country population in general exceeds $1 \%$ [17]. Basing on the said recommendations, we distributed all the Asian and African countries into three groups according to a stage in HIV epidemics that occurred in each of them.

Therefore, if migration from a country into Russia is insignificant in its scales but HIV prevalence in it can be considered the generalized stage in the epidemic process, than, obviously, this country is more dangerous in comparison with another one that "provides" more migrants but the epidemics in it is only at its initial stage.

The third stage was classifying countries as per threats they caused for the RF in general and RF regions in particular as regards HIV spread by migrants. At this stage we analyzed four groups of parameters:

\footnotetext{
${ }^{4}$ The Central Statistical Database of the RF Federal state Statistics Service (Rosstat). Available at: http://cbsd.gks.ru/ (date of visit January 12, 2018).

${ }^{5}$ According to UNAIDS and the WHO recommendations, when concentrated and generalized stages are concerned, it means HIV spreads among pregnant women. Due to lack of such statistical data on all the Asian and African countries over the examined time period, we considered it practicable to take all the population in general as a basis.
} 
1) migration flows from Asian and African countries into Russia, their scales having been identified at the first stage. We primarily paid our attention here to migration flows in 2015 taking into account the current threats. But at the same time migration flows by themselves can' be a "sufficient" parameter for analysis; given that, the overall number of migrants that came to Russia was multiplied by HIV prevalence in countries where migrants came from (\%). The obtained values showed a potential volume of HIV-infected migrants that came to Russia. Data as per countries were summed up, and after that we calculated a share of each country in the overall number of potential HIV-infected migrants. This parameter was given in the first column of the data array which we applied to perform our cluster analysis;

2) it is important to note that the threat of HIV spread in Russia exists not only at the country level, but at the regional one as well. We took a ratio of RF regions where migrants from Asian and African countries came to in 2015 to the overall number of RF regions as our second parameter;

3 ) but at the same time it is obvious that not only the last year out of the examined ones (2015) makes its contribution into occurring threats of HIV spread in the country. Probably, migrants from certain countries come to Russia persistently and every year, and as for other countries, it could be a single migration inflow in 2015. In order to level off the effect produced by the last year, we calculated a ratio of non-zero years for each country as per a number of migrants that came to Russia from it to the overall number of the examined years over the time periods which we had spotted out at the first stage, namely 1997-2000, 2003-2006, 2007-2010, and 2011-2016. This was the third parameter applied within the cluster analysis;

4) threats caused by each country are obviously determined not only by a share of HIV-infected people among its population. We determined a ratio between a number of those risk groups with more than $5 \%$ of people included into them being infected and the overall number of risks groups according to stages in epidemics development in each country. This was our fourth and final parameter.

We performed hierarchical cluster analysis as per Ward's method and four abovementioned parameters with SPSS Statistics 17.0 software; it allowed us to distribute 98 examined Asian and African countries into four groups as per a potential threat they caused for Russia in terms of HIV-infection spread. The threat could be extremely high, high, average, and low. The only exception was The Democratic People's Republic of Korea as there were no necessary data available for that country.

Results and discussion. We analyzed HIV spread among risk groups in Asian and African countries; our analysis revealed that at least one risk group existed in 84 out of 97 countries where more than $5 \%$ of its representatives were infected. It means that the initial stage in HIV epidemics is registered only in each eighth country in these two macro-regions. It is only natural that such countries are predominantly Muslim states in the Middle East and North Africa taking into account an existing inverse dependence between a share of Muslims in a country and HIV spread among population [18]. On the other hand, an effect produced by only one factor related to a religion can't provide a comprehensive explanation for HIV spread: thus, Indonesia is a world leader as per Muslim population [19] but this country has the highest ratio of risk groups with more than $5 \%$ of their representatives being $\mathrm{HIV}$-infected to the overall number of risk groups (4 out of 5). Still, the generalized stage in epidemics with HIV spreading beyond risk groups occurs only on the Seychelles and in continental African states south from Sahara excluding states located on the Horn of Africa and several Western African states. All the remaining countries (most of them are non-Muslim Asian countries) are somewhere in between in terms of HIV diffusion: there is the concentrated stage in epidemics and the infection spreads 
predominantly within several risk groups; however, it can spread beyond them in the nearest future.

At the same time, if we take a threat for our country related to HIV being spread by migrants, we can't state it is obvious that it is African states located to the south form Sahara that create the greatest migration inflows into our country. Indeed, recently more than a half of all migrants to Russia have been coming from three countries, namely Uzbekistan, Kazakhstan, and Tajikistan [20]. And only $0.2 \%$ of the relative number of migrants come from Nigeria that takes the leading place as per a number of migrants to Russia among African countries located to the south from Sahara.

We analyzed a potential threat of HIV spread for Russia caused by migrants coming from Asian and African countries; to do that, we multiplied a number of migrants coming to Russia by a share of HIV-infected people in these countries. It allowed us to detect that it was the first multiplier that made the main contribution. Thus, Uzbekistan, Kazakhstan, and Tajikistan could account for $52 \%$ of potentially HIV-infected migrants. At the same time two African countries, Namibia and Zambia, were also among top ten countries as per this parameter.

However, these quantitative values mostly describe the situation that existed in 20112015, and this period is the most significant but not the only one. Obviously, previous years in the examined time period can also make their contribution into the overall picture. Our analysis of those years during which this or that country "sent" migrants to Russia revealed that existing migration flows are extremely stable. Thus, over the examined period migrants from each of 98 Asian and African countries came to Russia at least once (that is, during at least one year). Besides, more than one third of such countries created annual migration flows to Russia, and all post-USSR states were among these countries, as well as most Northern African and Middle East states. And migrants from only 15 states came to Russia rarer that during each second year; these 15 states include Botswana, Eswatini, and the Seychelles which are dangerous in terms of HIV spread.

At the same time, migrants from some countries come to a lot of Russian regions while migrants from other countries come strictly to just several of them; that is, not only migration flows themselves are quite stable (including those with HIV-infected migrants) but also places where they go to. We analyzed distribution of migrants depending on a country of their origin and a region in the RF as a place where they came to stay and it allowed us to distribute all the flows into four groups (federal, macro-regional, regional and local ones). The greatest role in the process belongs to the flows from the first group coming from countries which "send" migrants to more than $3 / 4$ of the RF regions, namely all the post-USSR Asian states, as well as China, India, Turkey, Iran, and some other countries; there is only one African country among them and it is Egypt.

All the Asian and African countries were distributed into four groups as per potential threats for Russia related to HIV-infection spread; the threshold values for each group are given in Table 1:

1) countries that cause the maximum threats: Uzbekistan, Kazakhstan, and Tajikistan are among them;

2) countries that cause high threats: most North African and Middle East countries, South and East Asian countries, as well as Nigeria;

3) countries that cause average threats: most African countries located to the south from Sahara, Southeast Asian countries, as well as "exceptions" from the second group Libya, Saudi Arabia, Qatar, Kuwait, Nepal, Bangladesh, Sri-Lanka, Laos, Cambodia, and the Philippines;

4) countries that cause low threats: all the remaining countries but there are very few of them; this group includes Gambia, Liberia, Niger, Burkina Faso, Gabon, Congo, Malawi, Botswana, Eswatini, Lesotho, Eritrea, Djibouti, Oman, Brunei, Bhutan, and Myanmar. 
Threshold values of the examined parameters for Asian and African countries distributed into four groups as per threats for Russia caused by HIV-infection spread by migrants

\begin{tabular}{|l|c|c|c|c|}
\hline $\begin{array}{c}\text { Groups as } \\
\text { per a level } \\
\text { of threat }\end{array}$ & $\begin{array}{c}\text { A share of each } \\
\text { country in the } \\
\text { overall quantity of } \\
\text { potential HIV- } \\
\text { infected migrants } \\
\text { from all countries } \\
\text { to the RF }\end{array}$ & $\begin{array}{c}\text { A ratio of a number of } \\
\text { RF regions to which } \\
\text { migrants from each } \\
\text { country in a group came } \\
\text { to in 2015 to the overall } \\
\text { number of regions in } \\
\text { the RF }\end{array}$ & $\begin{array}{c}\text { A ratio of years that were } \\
\text { non-zero in terms of mi- } \\
\text { grants during which each } \\
\text { country from a group "sent" } \\
\text { migrants to the RF to the } \\
\text { overall number of years in } \\
\text { the examined time period }\end{array}$ & $\begin{array}{c}\text { A ratio of a number of } \\
\text { risk groups as per HIV } \\
\text { with more than 5\% of } \\
\text { their representatives } \\
\text { being HIV-infected to } \\
\text { the overall number of } \\
\text { risk groups }\end{array}$ \\
\hline $\begin{array}{l}\text { extremely } \\
\text { high }\end{array}$ & $0.142-0.206$ & 1.000 & 1.000 & 0.200 \\
\hline high & $0.000-0.096$ & $0.617-1.000$ & $0.938-1.000$ & $0.000-0.600$ \\
\hline average & $0.000-0.034$ & $0.074-0.519$ & $0.625-1.000$ & $0.000-0.800$ \\
\hline low & $0.000-0.015$ & $0.012-0.222$ & $0.063-0.563$ & $0.000-0.600$ \\
\hline
\end{tabular}

Conclusion. Our analysis allowed us to establish a contribution made by each of four quantitative parameters into a HIV-related threat caused by migration for Russia: the current situation with the infection spread in Asian and African countries, scales of overall migration flows from these countries to Russia as well as their differentiation as per their chronological features (over each year in an examined time period) and chorologic ones (migration to each of the RF regions). As we can see from Table 1, the greatest contribution is made exactly by the first component as Uzbekistan, Kazakhstan and Tajikistan that "send" the greatest quantities of migrants to Russia are included into a group that causes the maximum threat.

Similar contributions into the overall threat are made by a number of RF regions that accept potentially HIV-infected migrants from Asian and African countries and regularity of such directions in migration flows (the latter parameter here makes a bit higher contribution though). Finally, the smallest contribution is made by a number of risk groups with more than $5 \%$ of their representatives being HIV-infected in countries that "send" migrants to the RF. But still, effects produced by each component in the overall threat can grow stronger or, on the contrary, weaker. Thus, for example, a migration flow from Armenia has been almost similar to that from Tajikistan, but nevertheless, this Caucasian state is among countries that cause high, and not extremely high, threats; it is probably due to less significant HIV spread in it. On the other hand, Nigeria is more dangerous for Russia than the SAR where HIV is more widely spread. It is obviously due to much more considerable migration flows to the RF from this African country which has the greatest population in Africa.

So, if we consider two abstract countries, the former with the greater number of migrants coming form it to Russia but lower HIV incidence, and the latter, on the contrary, with smaller number of migrants bur high HIV incidence, we can state that the former will cause higher threat of HIV spread by migrants. Therefore, in spite of much more significant HIV spread in African countries located to the south from Sahara in comparison with Asian and Northern African countries, it is the latter states that create much more significant threats for Russia in terms of HIV spread by migrants. Nigeria is the only African country located to the south from Sahara that is similar to those states as per this parameter.

Funding. The research has been accomplished at the Institute for African Studies of the RAS and supported by the Russian Science Foundation within the project No. 17-78-10166 "Migration from Asia and Africa as a factor in the spread of HIV/AIDS in Russia: current status, regulation mechanisms, prospects for development".

Conflict of interests. The author declares there is no any conflict of interests. 


\section{References}

1. Borodkina O.I. Sotsial'nyi kontekst epidemii VICh/SPIDa v Rossii [A social context for HIV/AIDS epidemic in Russia]. Zhurnal issledovanii sotsial noi politiki, 2008, vol. 6, no. 2, pp. 151-176 (in Russian).

2. Denissov B.P., Sakevitch V.I. Dynamics of AIDs'/HIV epidemics. Sotsiologicheskie issledovaniya, 2004, no. 1, pp. 151-176 (in Russian).

3. Ruziyev M.M. HIV Epidemiology in the Republic of Tajikistan. VICh-infektsiya i immunosupressii, 2016, vol. 8, no. 4, pp. 55-59 (in Russian). DOI: 10.22328/2077-9828-2016-8-4-55-59

4. Agadjanian V., Zotova N. Structure, Culture, and HIV/STI Vulnerabilities among Migrant Women in Russia. Immigration and Health (Advances in Medical Sociology), 2019, vol. 19, pp. 47-67. DOI: $10.1108 / \mathrm{S} 1057-629020190000019003$

5. Tsapenko I.P., Sautkina V.A. Global migrations and health economics. Terra Economicus, 2018, vol. 16, no. 1, pp. 84-100 (in Russian). DOI: 10.23683/2073-6606-2018-16-1-84-100

6. Pokrovsky V., Ladnaia N., Pokrovskaya A. HIV/AIDS reduces the number of Russians and their life expectancy. Demograficheskoe obozrenie, 2017, vol. 4, no. 1, pp.65-82 (in Russian). DOI:10.17323/demreview.v4i1.6988

7. Korita T.V., Ivanov A.N., Balahontseva L.A., Trotsenko O.E. The role of immigrants in the development of HIV epidemic in the far eastern federal district. Dal'nevostochnyi zhurnal infektsionnoi patologii, 2012, no. 21, pp. 74-83, (in Russian).

8. Dmitriev R.V. Transformatsiyasotsial'no-ekologicheskoisituatsiipoVICh-infektsii v SeveroKavkazskom federal'nom okruge pod vliyaniem vneshnei migratsii [Transformation of a social and ecological situation as regards HIV-infection in the North Caucasian Federal District caused by external migration]. Yug Rossii: ekologiya, razvitie, 2019, vol. 14, no. 3, pp. 115-123 (in Russian). DOI: 10.18470/19921098-2019-3-115-123

9. Belyakov N.A., Vinogradova T.N., Panteleyeva O.V., Kosenko Yu.Yu., Tikhonova Ye.M., Logvinenko A.A., Dement'yeva N.Ye., Rakhmanova A.G. Investigation into HIV prevalence among foreign migrants in Saint-Petersburg, russia. VICh-infektsiya i immunosupressii, 2014, vol. 6, no. 4, pp. 7-16 (in Russian). DOI: 10.22328/2077-9828-2014-6-4-7-16

10. Mikhaylova Yu.V., Nechaeva O.B., Shikina I.B., Sorokin V.N. Impact of migration factor on TB and HIV epidemic situation in Russia. Sotsial'nye aspekty zdorov'ya naseleniya, 2018, vol. 62, no. 4, pp. 1-18 (in Russian). DOI: 10.21045/2071-5021-2018-62-4-4

11. Kalacheva G.A., Rubina Y.L., Rudakov N.V., Buslova L.E. Epidemiologicheskie aspekty VICh-infektsii sredi trudovykh migrantov [Epidemiologic aspects of HIV-infection among labor migrants]. Zhurnal infektologii, 2017, vol. 9, no. 4, pp. 105 (in Russian).

12. Kalacheva G.A., Rubina Y.L., Rudakov N.V., Buslova L.E. Migration workers and HIV in Siberia. VICh-infektsiy i immunosupressii, 2018, vol. 10, no. 3, pp. 102-107 (in Russian).DOI: 10.22328/2077-9828-2018-10-3-102-107

13. Rafiev H.K., Latipov A.L., Rafieva Z.H. Epidemiological situation on AIDs between migrants to Tajikistan. Vestnik Avitsenny, 2008, vol. 37, no. 4, pp. 78-81 (in Russian).

14. Amirkhanian Yu.A., Kuznetsova A.V., Kelly J.A., Di Franceisco W.J., Musatov V.B., Avsukevich N.A., Chaika N.A., McAuliffe T.L. Male Labor Migrants in Russia: HIV Risk Behavior Levels, Contextual Factors, and Prevention Needs. Journal of Immigrant and Minority Health, 2011, vol. 13, no. 5, pp. 919-928. DOI: 10.1007/s10903-010-9376-y

15. AIDSinfo. UNAIDS. Available at: http://aidsinfo.unaids.org/ (12.01.2018).

16. HIV/AIDS. World Health Organization. Available at: http://www.who.int/hiv/data/en/ (28.01.2018).

17. Brookmeyer R. Measuring the HIV/AIDS Epidemic: Approaches and Challenges.Epidemiologic Reviews, 2010, vol. 32, no. 1, pp. 26-37. DOI: https://doi.org/10.1093/epirev/mxq002

18. Speakman S. Comparing the Impact of Religious Discourse on HIV/AIDS in Islam and Christianity in Africa. Vanderbilt Undergraduate Research Journal, 2012, no. 8, pp. 1-7. DOI: https://doi.org/10.15695/vurj.v8i0.3490 
19. Gorokhov S.A., Dmitriev R.V. The components of the Christian population dynamics at the beginning of the 21st century: world, region, country. Vestnik Tomskogo gosudarstvennogo universiteta, 2017, no. 418, pp. 85-90 (in Russian). DOI: 10.17223/15617793/418/11

20. Arkhangelsky V.N., Danilova I.A., Dmitriev R.V., Khasanova R.R. Prospects of the demographic development of Russia until the MID-century. Narodonaselenie, 2017, vol. 77, no. 3, pp. 24-36 (in Russian). DOI: 10.26653/1561-7785-2017-3-2

Dmitriev R.V. Assessing potential threat of hiv-infection spread in Russia by migrants from asian and african countries. Health Risk Analysis, 2019, no. 3, pp. 66-73. DOI: 10.21668/health.risk/2019.3.08.eng

Received: 04.04.2019

Accepted: 08.08.2019

Published: 30.09.2019 